\title{
Physicochemical and sensory properties of grape juices produced from different cultivars and extraction systems
}

\section{Propriedades físico-químicas e sensoriais de sucos de uva elaborados com diferentes cultivares e sistemas de extração}

\author{
Angelica Bender ${ }^{1 *}$; André Luiz Kulkamp de Souza2; Marcelo Barbosa Malgarim; \\ Vinicius Caliari2; Pedro Kaltbach; Vagner Brasil Costa ${ }^{3}$
}

\section{Highlights}

Influence of enzymatic and steam extraction systems on grape juice composition.

Adjustment of juices to the identity and quality standards for whole fruit juice.

Behavior of different grape cultivars under different extraction systems.

\begin{abstract}
The objective of the present study was to evaluate grape juices from different cultivars obtained by two different technologies: steam juicer system (S1) and enzymatic system (S2). The beverages were evaluated for physicochemical and sensory characteristics and their adequacy to the identity and quality standards of whole grape juice. Experiments were carried out in the 2018 and 2019 harvests with the grape cultivars BRS Rúbea (RUB), BRS Cora (COR), BRS Violeta (VIO), BRS Carmem (CAR), BRS Magna (MAG), Bordô (BOR), Isabel (ISA), Isabel Precoce (IP), Concord (CON), Concord Clone 30 (C30) and SCS 421 Paulina (SCSP). Treatments followed factorial design (cultivars $x$ extraction system). S1 resulted in juices with lower soluble solids content; on average, a reduction of $3.12^{\circ} \mathrm{Brix}$ in 2018 and $2.30^{\circ} \mathrm{Brix}$ compared with the original content in grapes. Among S1 juices, only VIO and MAG in 2018, and VIO and CAR in 2019 achieved the minimum value of soluble solids ( $14^{\circ} \mathrm{Brix}$ ) established by the Brazilian legislation. Juices of SCSP and CON in 2018 and C30, CON and RUB in 2019 presented values lower than $14^{\circ}$ Brix, independent of the extraction system. S2 juices were characterized by higher values of total acidity, soluble solids, reducing sugars, anthocyanins, global impression, and equilibrium, as well as lower values of lightness for most of the cultivars.
\end{abstract}

Key words: Standards. Identity. Soluble solids. Whole juice. Steam juicer. Enzymatic.

1 Students of the Postgraduate Course in Agronomy-Fruit in Temperate Climate, Federal University of Pelotas, UFPel, Pelotas, RS, Brazil. E-mail: bender.angelica.fruti@gmail.com; pedrokaltbach@gmail.com

2 Drs., Researcher, Brazilian Agricultural Research Company, EPAGRI, Videira, SC, Brazil. E-mail: andresouza@epagri. sc.gov.br; caliari@epagri.sc.gov.br

${ }^{3}$ Profs. Drs., Course in Agronomy-Fruit in Temperate Climate, Federal University of Pelotas, UFPel, Pelotas, RS, Brazil. E-mail:malgarim@yahoo.com; vagnerbrasil@gmail.com

* Author for correspondence

Received: Oct. 05, 2020 - Approved: Dec. 01, 2020 


\section{Resumo}

O objetivo deste estudo foi avaliar sucos de uva elaborados com diferentes cultivares pelos sistemas de extração a vapor (S1) e sistema enzimático (S2) quanto à qualidade físico-química, sensorial e adequação aos padrões de identidade e qualidade para suco de uva integral. Os sucos foram elaborados nas safras 2018 e 2019 pelos sistemas de S1) e S2 com os cultivares BRS Rúbea (RUB), BRS Cora (COR), BRS Violeta (VIO), BRS Carmem (CAR), BRS Magna (MAG), Bordô (BOR), Isabel (ISA), Isabel Precoce (IP), Concord (CON), Concord Clone 30 (C30) e SCS 421 Paulina (SCSP). Os tratamentos foram arranjados em esquema bifatorial (cultivares x sistemas de extração). Quando empregado o S1, observa-se redução média de 3,12 ${ }^{\circ} \mathrm{Brix}$ em 2018 e 2,30 ${ }^{\circ}$ Brix em 2019 nos sucos com relação à uva que lhes originou. No S1, apenas os sucos de VIO e MAG em 2018 e VIO e CAR em 2019 atingiram o valor final mínimo (14 ${ }^{\circ}$ Brix) estabelecido em lei para sólidos solúveis. Os sucos dos cultivares SCSP e CON em 2018 e C30, CON e RUB em 2019, apresentaram sólidos solúveis baixo do preconizado, independente do sistema de extração. Os sucos obtidos pelo S2 caracterizaram-se por valores mais elevados de acidez total, sólidos solúveis, açúcares redutores, antocianinas, impressão global e equilíbrio e mais baixos de luminosidade para a maioria das variedades.

Palavras-chave: Padrões. Identidade. Sólidos solúveis. Suco integral. Arrastre de Vapor. Enzimático.

\section{Introduction}

The elaboration of grape juice is an economical alternative for traditional wine industries, cooperatives, small producers and agro-industries. The production of juices using Brazilian grapes has been characterized by some distinct profiles. On the one hand, there is that represented by large, highly technologyoriented companies that use heat-exchanger extraction known as enzymatic or tube-in-tube system; on the other production consisting of small family enterprises, which elaborate the homemade juices, obtained by the steam extraction system (Frölech et al., 2019; Marcon et al., 2016).

The steam extraction of grape juice represents an alternative for small farmers to make the small rural property economically viable. It is a widespread system in rural properties in the highland region of the State of Rio Grande do Sul (Costa et al., 2019; Marcon et al., 2013). The key factor that leads to the production of grape juice by an extractor pan is that the apparatus is simple, relatively inexpensive and easy to handle. The resulting juice is basically sold at family farming fairs and to consumers around the producing property, adding value to the raw material and increasing household income (Canossa et al., 2017; Guerra, Bitarelo, \& Ben, 2016).

Although the pans are easy to use, have a low cost of implantation and provide good quality juices, this process can lead to an incorporation of exogenous water, due to the condensation of the steam used to extract the juice (Bender, Souza, Caliari, Malgarim, \& Camargo, 2019; Bresolin, Gularte, \& Manfroi, 2013; Marcon et al., 2016). The percentage of water incorporation in the juices made through the extraction pans varies from $7.56 \%$ to 20.7\% (Marcon et al., 2016). The incorporation of water in the juice does not constitute health problems for the consumer. However, if the water added to the juice is not declared, through the name of the beverage, the consumers may be buying a product that does not meet their expectations (Bresolin et al., 2013). 
In 2010, discussions were started on the incorporation of water in steamextracted juices and the consequence of this on the classification of this product under the legislation, which defines whole grape juice as that which is found in its natural contente without the addition of sugar (Decreto $n^{\circ} 8.198$, 2014), therefore, extractor pan juice would be classified as nectar, a beverage that contains at least 50\% grape juice (Instrução Normativa $\left.n^{\circ} 24,2012\right)$.

The vast majority of producers, farmers who process the raw material they produce, were dissatisfied with this new condition, considering that this name would depreciate the product, which is natural, pure and without additives. From then on, research work was started to solve this issue, and one of the possible solutions would be creating a new name, exclusive for the product obtained by the steam extraction method (Bresolin et al., 2013; Roldan, 2016). However, until now, a new classification has not been defined for steamextracted juices.

Therefore, the objective of this study was to evaluate grape juices elaborated from different cultivars through the steam extraction and enzymatic systems in terms of physicochemical and sensory characteristics, as well as the adequacy to the identity and quality standards for whole grape juice.

\section{Material and Methods}

Evaluation was carried out during the 2018 and 2019 harvests. The grapes used were produced in an experimental vineyard of the EPAGRI - Agricultural Research and Rural Extension Company of Santa Catarina, Videira Experimental Station (Videira, SC/Brazil), located under coordinates $27^{\circ} 02^{\prime} 27,59^{\prime \prime} \mathrm{S}$, $51^{\circ} 08^{\prime} 04,73^{\prime \prime} \mathrm{W}$, at an altitude of 830 meters above sea level. According to Köppen, the region's climate is classified as humid mesothermal and mild summer (Cfb). The average temperature and the accumulated precipitation during the months that comprise the maturation of the grapes (December to March) were $21.4^{\circ} \mathrm{C}$ and $252.20 \mathrm{~mm}$ in 2018 and $21.9^{\circ} \mathrm{C}$ and $889.80 \mathrm{~mm}$ in 2019 , respectively.

The grapes evaluated in this study were: BRS Rúbea (RUB), BRS Cora (COR), BRS Violeta (VIO), BRS Carmem (CAR), BRS Magna (MAG), Bordô (BOR), Isabel (ISA), Isabel Precoce (IP), Concord (CON), Concord Clone 30 (C30) and SCS 421 Paulina (SCSP), produced in an experimental vineyard, implanted in 2008 through the $Y$-structure conduction system under the rootstock VR 043-43 in $3.0 \times 2.0 \mathrm{~m}$ spacing, between rows and between plants, respectively, adopting the mixed pruning system. The cultivar BRS Magna was only evaluated in the 2018 harvest due to the high incidence of downy mildew in the 2019 harvest, which affected the productivity of this cultivar in the studied area. The values of soluble solids and titratable acidity of the grapes (must) before processing are listed in Table 1. 
Table 1

Average values of soluble solids and total acidity, in grapes for juice production in the 2018 and 2019 harvests

\begin{tabular}{|ccccc|}
\hline \multirow{2}{*}{ Cultivars } & \multicolumn{2}{c|}{ Soluble Solid ('Brix) } & \multicolumn{2}{c|}{ Total Acidity $\left(\mathrm{mEq} \cdot \mathrm{L}^{-1}\right)$} \\
\cline { 2 - 5 } C30 & 2018 & 2019 & 2018 & 2019 \\
VIO & 15.66 & 13.02 & 70.00 & 75.50 \\
IP & 17.42 & 15.12 & 72.52 & 57.80 \\
MAG & 16.74 & 15.40 & 63.04 & 72.60 \\
\hline BOR & 16.50 & - & 75.42 & - \\
SCSP & 14.90 & 14.50 & 51.20 & 57.40 \\
\hline CON & 14.30 & 13.74 & 40.02 & 55.23 \\
COR & 13.50 & 14.02 & 82.60 & 49.00 \\
\hline RUB & 16.00 & 15.20 & 134.42 & 90.80 \\
\hline ISA & 14.70 & 12.80 & 100.56 & 62.40 \\
\hline CAR & 16.08 & 15.80 & 94.20 & 60.14 \\
\hline
\end{tabular}

C30-Concord Clone 30; VIO- BRS Violeta; MAG- BRS Magna; BOR- Bordô; IP-Isabel Precoce; CON- Concord; SCSP SCS 421 Paulina; RUB- BRS Rúbea; COR- BRS Cora; ISA- Isabel Precoce; CAR- BRS Carmem.

After harvesting, the grapes were taken to an experimental winery where juices were prepared according to the following steps:

Steam Extraction (S1): The must was extracted using a juice extractor or extractor pan with a capacity of $20 \mathrm{~kg}$ of fruit. Initially, the berrieswere destemmed with theaid of a manual destemmer and later placed in a perforated container, fitted in the external container and both coupled over the water tank, which was accommodated on a gas stove, for steam generation. After approximately $40 \mathrm{~min}$, the wort began to flow through the outlet tube and was collected in a container for homogenizing the juice, kept on fire to keep the juice warm. The bottling of the samples occurred as soon as the solid mass was depleted of liquid, and the filling occurred at a temperature of $86^{\circ} \mathrm{C}$ to guarantee microbiological stability.
Enzymatic Extraction (S2): it was adapted to simulate a heat exchanger system. The berries were destemmed with the aid of a manual destemmer, subsequently heated to $50{ }^{\circ} \mathrm{C}$, where they remained in constant homogenization for approximately $20 \mathrm{~min}$, until the must reached the desired temperature $\left(50{ }^{\circ} \mathrm{C}\right)$. Then, a commercial thermo-resistant enzyme complex was added (Pectinex Ultra SP-L) at a concentration of $3 \mathrm{~g} \cdot \mathrm{hL}^{-1}$, followed by continuous maceration for one hour. Subsequently, pressing was performed to separate the liquid, which was taken to the cold chamber at a temperature of $\pm 1^{\circ} \mathrm{C}$ for 24 $\mathrm{h}$ to decant the solid particles. The following day, the juice was transferred, pasteurized and bottled at a temperature of $86^{\circ} \mathrm{C}$.

The experimental design used was completely randomized, with three 
replications. The treatments were arranged in a two-factor scheme. Treatment factor $A$ tested the cultivars (RUB, COR, VIO, CAR, MAG, BOR, ISA, IP, CON, C30 and SCSP) and factor B the extraction systems (steam and enzymatic). Five glass bottles $(500 \mathrm{~mL}$ ) were used for each treatment; three of which were chosen at random for physicochemical and colorimetric analyses and the determination of bioactive compounds. The rest of the samples were used for sensory analysis.

The soluble solids content ( ${ }^{\circ}$ Brix), $\mathrm{pH}$ and total titratable acidity $\left(\mathrm{mEq} \mathrm{L}^{-1}\right)$ were carried out according to the methodologies defined by the Ministry of Agriculture (Instrução Normativa $\left.n^{\circ} 24,2005\right)$. For total sugars $\left(\mathrm{g} \mathrm{L}^{-1}\right)$, the DNS method described by Maldonade, Carvalho and Ferreira (2016), adapted for grape juice, was used. The lightness $\left(L^{*}\right)$ of the juices was determined in a spectrophotometer and expressed in the CIELab system, with the scale varying from black $(0$, dark) to white $(100$, light) (Chitarra \& Chitarra, 2005).

The content of total phenolic compounds was determined spectrophotometrically using the Folin-Ciocalteu colorimetric method (Singleton \& Rossi, 1965), and expressed as mg of gallic acid (GAE) $L^{-1}$. The total content of monomeric anthocyanins was determined using the differential $\mathrm{pH}$ method (Giusti \& Wrolstad, 2001), the results were expressed as $\mathrm{mg} \mathrm{L}^{-1}$ of cyanidin-3-glycoside.

The sensory evaluation of the juices was performed by mixed quantitative analysis (Associação Brasileira de Normas Técnicas [ABNT], 2019). The attributes color intensity, acidity, sweetness, acidity/sweetness equilibrium and global impression were evaluated on a nine-point unstructured scale, anchored by the extremes "little intense" and "very intense", "low concentration" and "high concentration", "small concentration" and "great concentration" and "really disliked" and "really liked". The comprehension of the attributes and descriptors by the assessors was evaluated during the selection and training of the evaluation panel. The training was carried out during 6 months before the tests. The samples were coded using random three-digit numbers, served randomly in glasses, at room temperature. The sensory panel had 10 trained assessors who agree to participate (research approved by the Ethics Committee of the Federal University of Pelotas, CAAE 92226218.8.0000.5317) and performed the sensory tests in individual booths at the Beverages Sensory Laboratory at the EPAGRI Experimental Station in Videira-SC.

The data obtained were analyzed for normality using the Shapiro Wilk test, homoscedasticity using the Hartley test; and, the independence of residues by graphical analysis. Subsequently, the data were subjected to analysis of variance using the $F$ test $(p \leq 0.05)$. With statistical significance, the effects of varieties and extraction systems were compared using the Scott Knott test ( $p \leq 0.05)$.

Principal component analysis (PCA) was performed using mean values (mean performance of each cultivar over the two seasons observed, one crop for MAG) using the physicochemical and sensory variables. The criterion for disposal of the principal components (PCs) used was recommended by Jolliffe (2002), establishing that a number of PCs that includes at least between 70 and $90 \%$ of the total variance should be retained. A cluster analysis was also performed on this same set of data in order to group individuals 
according to their main characteristics. For these analyses, the software R (R Core Team [R], 2020) and the interface RStudio (RStudio Team [RStudio], 2020) were used, as well as the packages Factominer (Lê, Josse, \& Husson, 2008) and Factoshiny (Vaissie, Monge, \& Husson, 2020).

\section{Results and Discussion}

The results of the physicochemical variables showed an interaction between the evaluated treatment factors (varieties $x$ extraction systems), as listed in Tables 2 and 3.

The $\mathrm{pH}$ did not differ between the extraction methods for the juices of $\mathrm{C} 30$ and CAR in 2018. For VIO and IP, the highest $\mathrm{pH}$ values were obtained in S2 and, while for the other cultivars, these occurred in S1. In 2019, the extraction system influenced the $\mathrm{pH}$ of the juices of C30, IP, BOR, CON, RUB and CAR. The lowest $\mathrm{pH}$ values were obtained in the juices of CON (2.96) in S2 in 2018, C30 (2.99), CON (2.99) in S1 and RUB (2.97) in S2 in 2019. The $\mathrm{pH}$ is not a parameter required by legislation; however, it is important due to its influence on the color and stability of anthocyanins, which are more stable in acidic solutions than in neutral and alkaline solutions (Malacrida \& Motta, 2005). Mota et al. (2018) evaluated steam-extracted juices of the cultivars IP, CAR, $\mathrm{BOR}, \mathrm{VIO}$ and $\mathrm{C} 30$ and $\mathrm{pH}$ values ranged from 3.40 to 3.90. Rizzon and Miele (2012) reported an average value of 3.31 for commercial whole grape juices. Canossa et al. (2017) obtained pH values of 2.93 for CON, 2.99 for IP and 3.16 for BOR juices.

The soluble solids content varied between cultivars, as well as between extraction systems in the evaluated crops
(Table 2). The juices obtained by S2 showed higher values of soluble solids for all cultivars in 2018 and 2019. The lowest values were obtained in the juices of the SCSP cultivar $10.70^{\circ}$ Brix and $11.03^{\circ} \mathrm{Brix}$ in $\mathrm{S} 1$; the highest values were $17.90^{\circ} \mathrm{Brix}$ and $16.70^{\circ} \mathrm{Brix}$ for ISA in S2, in 2018 and 2019, respectively.

Rizzon and Link (2006) explain that lower values of soluble solids are due to the effect of the dilution of the water vapor used in heating and in the stream extraction process. Marcon et al. (2016) found lower average values for juices prepared by an extraction pan (12.70 ${ }^{\circ} \mathrm{Brix}$ ) compared to those obtained by heat exchangers $\left(15.80^{\circ} \mathrm{Brix}\right)$, justifying that the lowest results are due to the incorporation of $18.6 \%$ of water in the juice when using the steam extraction method. Roldan (2016) obtained lower soluble solids values in juices of the BOR cultivar extracted by different extraction apparatus that employ steam distillation compared to the enzymatic system, justifying the difference by incorporating 0 to $23 \%$ water at the end of the extraction process.

When comparing the soluble solids values of grapes (must) before processing (Table 1 ) with the results of the juice (Table 2), an average reduction of $3.12^{\circ} \mathrm{Brix}$ in 2018 and $2.30^{\circ} \mathrm{Brix}$ in 2019 is observed in juices in relation to the grapes when $\mathrm{S} 1$ is employed. These results agree with those described by Marcon (2013), who evaluated juices extracted by different equipment that use steam as a means of heating the grapes. On a laboratory scale, the initial mean value was $18.90^{\circ} \mathrm{Brix}$ for the must of cultivars BOR/CON and $17.70^{\circ} \mathrm{Brix}$ for ISA, and for juices the values were 15.80 ${ }^{\circ}$ Brix for BOR/CON and $14.70{ }^{\circ}$ Brix for ISA, showing a decrease of $3.07^{\circ} \mathrm{Brix}$ and $3.03^{\circ} \mathrm{Brix}$, respectively (Marcon, 2013). Mota et al. (2018) found a reduction in ${ }^{\circ}$ Brix when comparing 
the grapes with the juice prepared by steam distillation for the cultivars IP, CAR, BOR, VIO and $\mathrm{C} 30$, where the values in the grapes varied from $16.90{ }^{\circ}$ Brix for IP to $18.70{ }^{\circ}$ Brix for CAR and in the juices the values ranged between $12.4^{\circ} \mathrm{Brix}$ for BOR and $15.00^{\circ} \mathrm{Brix}$ for VIO. For the juices obtained by $\mathrm{S} 2$, the values remained very close to those found in the grapes, and in some varieties the values of soluble solids in the juices were slightly higher than those of the musts. This behavior may be the result of a higher contente of soluble solids, because the juices were under continuous maceration during processing in contact with pectinases, which facilitates the extraction of the grape components into the juice, while the musts were obtained by simply crushing the grape before processing.

As for the adequacy to identity and quality standards for the variable soluble solids for whole grape juices, only the juices of VIO (14.07 ${ }^{\circ}$ Brix) and MAG (14.80 ${ }^{\circ}$ Brix) in 2018 and VIO (14.03 $\left.{ }^{\circ} \mathrm{Brix}\right)$ and CAR (14.03 $\left.{ }^{\circ} \mathrm{Brix}\right)$ in 2019 reached the minimum value established $(14.00$ 'Brix) when elaborated by $\mathrm{S} 1$. In the juices obtained by $\mathrm{S} 2$, the content of soluble solids was not met by the juices of $\operatorname{SCSP}\left(13.63^{\circ} \mathrm{Brix}\right)$ and CON (13.10 ${ }^{\circ} \mathrm{Brix}$ ) in 2018, as well as C30 (12.80 $\left.{ }^{\circ} \mathrm{Brix}\right), \mathrm{CON}\left(13.73^{\circ} \mathrm{Brix}\right.$ ) and RUB (13.20 $\left.{ }^{\circ} \mathrm{Brix}\right)$ in 2019.

The inadequacy of the juices prepared by $\mathrm{S} 1$ can be justified by incorporating water in the process, as discussed above. Borges, Roberto, Yamashita, Assis and Yamamotoi (2014) explain that in order to reach the value of $14^{\circ} \mathrm{Brix}$ in juices produced in an extraction pan by the steam distillation method, it is important that the soluble solids content of the must be slightly higher, since this method generally promotes a small dilution of the must, by adding the water vapor, thus reducing the SS contents of the juice. As for the juices obtained by S2, the values below the minimum defined for whole juices can be explained by the difficulty of the cultivars to reach the ideal maturation in the region of study, due to the high rainfall in the maturation period, especially in the year of 2019 which presented a higher index from December to March. According to Brighenti et al. (2018), in the south and southeast regions of Brazil, the maturation period of the BOR grape coincides with the rainy season and, in certain situations, the cultivar does not reach a satisfactory soluble solids ratio to produce quality juices. Costa et al. (2019) also found values below the legislation in BOR (11.37 and $13.00{ }^{\circ}$ Brix) and CON (13.37 and 13.27 ${ }^{\circ}$ Brix) steam-extracted juices produced in the Campanha region of Rio Grande do Sul. Borges et al. (2014) evaluated the quality of the cultivar CON in Rolândia-PR, verifying that in the two studied harvests (2010 and 2011) the final period of maturation was marked by intense rainfall, which may have contributed to the must dilution and reduction in the soluble solids content. Mandelli (2002) obtained a significant negative correlation between the contentes of soluble solids and excess water, for CON, in Serra Gaúcha (RS).

Regarding total acidity, all juices obtained higher values when produced by S2 when compared to those produced by S1, for all cultivars, with the exception of MAG in 2018, which showed no difference between the extraction systems (Table 2). Regardless of the extraction system employed, all juices met the legal specification of at least $55 \mathrm{mEq}$ $\mathrm{L}^{-1}$, with values ranging from $90.70 \mathrm{mEq} \mathrm{L}^{-1}$ for SCSP in S1 to $191.09 \mathrm{mEq} \mathrm{L}^{-1}$ for CON in S2 in 2018 and $73.91 \mathrm{mEq} \mathrm{L}^{-1}$ for CAR in S1 and 


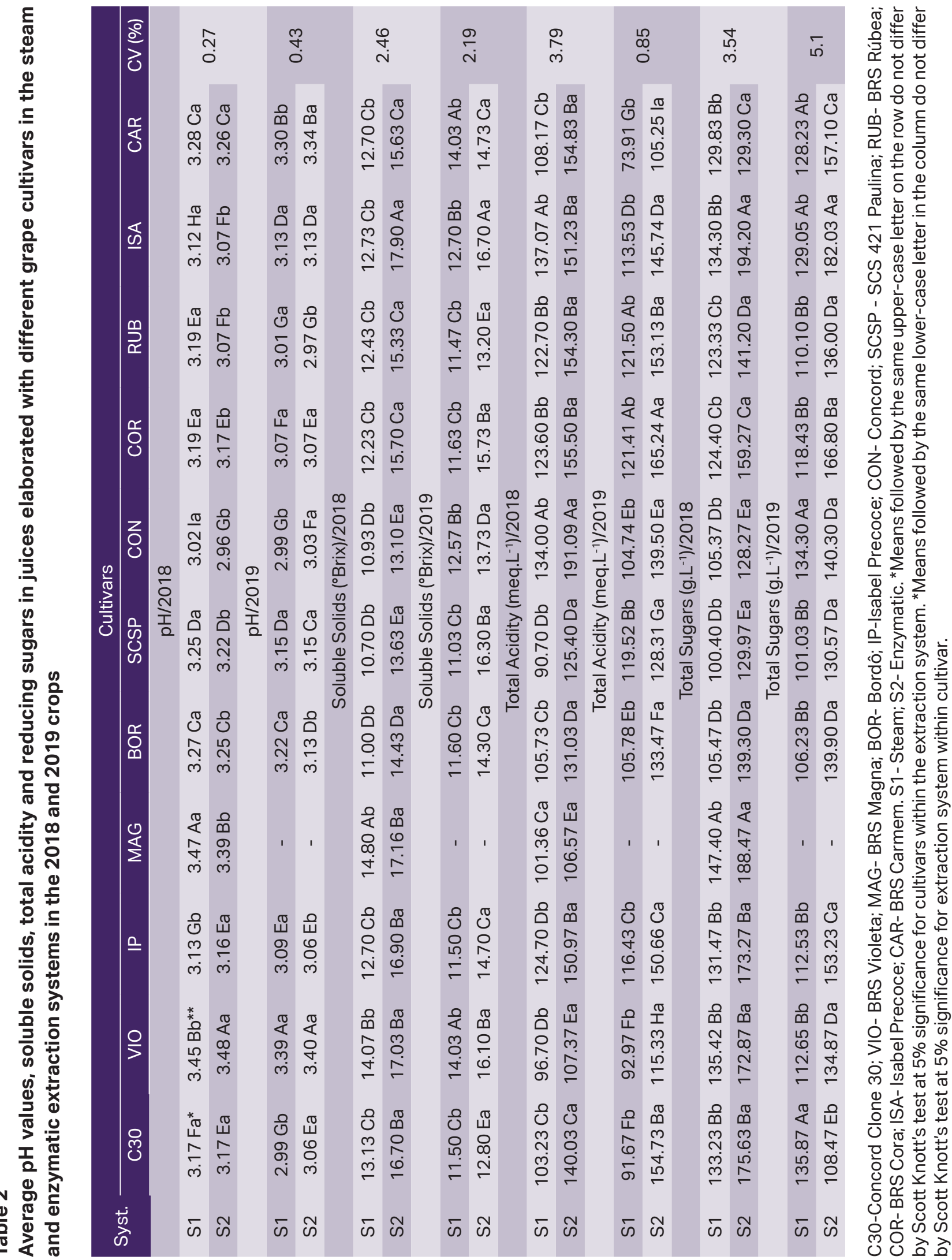




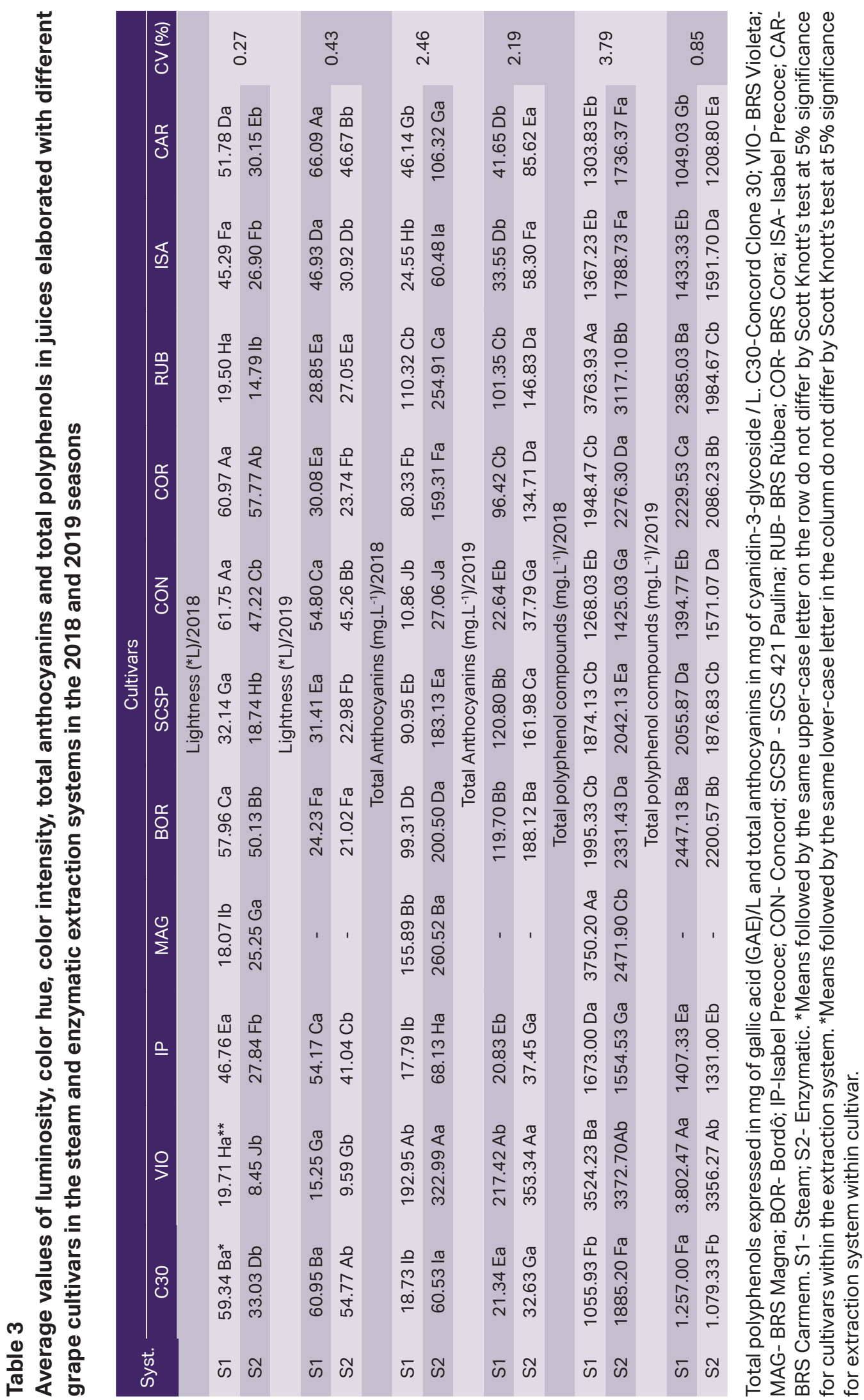


165.24 mEq L-1 for COR in S2 in 2019. Costa et al. (2019) obtained values of $98.95 \mathrm{mEq} \mathrm{L}^{-1}$ and $96.35 \mathrm{mEq} \mathrm{L}^{-1}$ for BOR and $88.82 \mathrm{mEq} \mathrm{L}^{-1}$ and $88.35 \mathrm{mEq} \mathrm{L}^{-1}$ for $\mathrm{CON}$, these results were below those verified in the present study for both extraction systems, with the exception of SCSP $\left(90.70 \mathrm{mEq} \mathrm{L}^{-1}\right)$ and VIO $(96.70 \mathrm{mEq}$ $\left.\mathrm{L}^{-1}\right)$ juices in 2018 and $\mathrm{C} 30$ (91.67 $\left.\mathrm{mEq} \mathrm{L}^{-1}\right)$ and VIO (92.97 mEq L-1) in 2019, when prepared by S1. Bender et al. (2019) evaluated C30 juices produced in Videira-SC, prepared by an adapted system simulating heat exchanger and equipment referred to as whole fruit juicer, obtaining total acidity values from $162.90 \mathrm{mEq}$ $\mathrm{L}^{-1}$ to $175.70 \mathrm{mEq} \mathrm{L}^{-1}$, respectively. Canossa et al. (2017) obtained results of $95.68 \mathrm{mEq} \mathrm{L}^{-1}$ for CON juices, $109.38 \mathrm{mEq} \mathrm{L}^{-1}$ for IP and 124.79 $\mathrm{mEq} \mathrm{L^{-1 }}$ for BOR produced by steam distillation in the municipality of Lages-SC.

Rizzon and Link (2006) state that the technology used in the processing of juices can result in different extraction of substances present in the grape skins, leading to important variations in the chemical composition of the product. Rizzon, Meneguzzo and Manfroi (1998) observed that the high acidity comes from the content of fixed acids in the skin, released to the juice in the elaboration process. The use of high temperatures can cause plasmolysis of the membrane and rupture of cells in the fruit wall, facilitating the release of water, as well as the extraction of acids from the skin and seeds that contribute to greater total acidity (Ribéreau-Gayon, Dubourdieu, Donèche, \& Lovaud, 2006; Lima et al., 2015; Mota et al., 2018).

In 2018, all the evaluated juices showed higher total sugar contentes when prepared by S2 (Table 2). The results were similar in 2019, in terms of extraction systems, except for the CON cultivar juices (134.30 $\left.\mathrm{g} \mathrm{L}^{-1} ; 140.30 \mathrm{~g} \mathrm{~L}^{-1}\right)$, which did not show difference and for C30, which had the highest sugar concentration in the juices prepared in S1 $\left(135.87 \mathrm{~g} \mathrm{~L}^{-1}\right)$ compared to S2 (108.47 $\left.\mathrm{g} \mathrm{L}^{-1}\right)$. The highest sugar content was found in ISA juices $(194.20 \mathrm{~g}$ $\left.\mathrm{L}^{-1}\right)$ followed by MAG $\left(188.47 \mathrm{~g} \mathrm{~L}^{-1}\right)$ both made in extraction S2 in 2018 and in ISA juices (182.03 $\left.\mathrm{g} \mathrm{L}^{-1}\right)$ also in S2 in 2019. The sugar content of grape must represent about $90 \%$ to $95 \%$ of the total soluble solids and the amount of sugar in the juice depends on the variety and the level of ripeness of the grape (Rizzon et al., 1998); thus the higher results for total sugars in S2 can be justified by the greater extraction as a function of the maceration with the addition of pectinolytic enzymes which resulted in higher contentes of total sugars.

Marcon (2013) found higher values in the juices extracted by heat exchanger method compared to the steam system. The levels of total sugars found in the juices ranged from $141.00 \mathrm{~g} \mathrm{~L}^{-1}$ to $175.00 \mathrm{~g} \mathrm{~L}^{-1}$ (Bordeaux) and from $140.00 \mathrm{~g} \mathrm{~L}^{-1}$ to $197.00 \mathrm{~g} \mathrm{~L}^{-1}$ (Isabel), indicating a dilution promoted by the steam originating in the extraction process. Mota et al. (2018) obtained values of $118.10 \mathrm{~g} \mathrm{~L}^{-1}$ for IP, $127.60 \mathrm{~g} \mathrm{~L}^{-1}$ for CAR, $98.5 \mathrm{~g} \mathrm{~L}^{-1}$ for BOR, 125.40 $\mathrm{g} \mathrm{L}^{-1}$ for $\mathrm{VIO}$ and $112.80 \mathrm{~g} \mathrm{~L}^{-1}$ for C30. Fongaro, Cavagnolli and Spada (2016) evaluated the database of analysis of grape juices in an oenological reference laboratory in Flores da Cunha from the years 2012 to 2016, finding average values that varied from $133.00 \mathrm{~g} \mathrm{~L}^{-1}$ in 2016 to $152.00 \mathrm{~g} \mathrm{~L}^{-1}$ in 2013 for red juices.

In general, the evaluated juices showed greater lightness when prepared by S1 (Table 3), except for MAG (25.25), which had the highest value in S2 in 2018 and BOR (24.23; $21.02)$ and RUB $(28.85 ; 27.05)$ that did not differ in 2019. In 2018, the highest lightness in S1 was obtained in the CON (61.75) and COR 
(60.97) juices and the lowest in MAG (18.05). In S2 the highest value was in COR (57.77) and the lowest being VIO (8.45). In 2019 the highest lightness was in CAR (66.09) and C30 (54.77) in S1 and S2, respectively, the lowest result was found in VIO $(15.25 ; 9.59)$ in both extraction systems. The lower the $L^{*}$ value, the darker the sample (Bender et al., 2020), which proves the greater extraction of compounds responsible for color in S2. Marzarotto (2005) and Marcon et al. (2013) explain that the juice production technology affects the extraction of substances present in the grape skins, with the most important factors being the temperature and the extraction time.

The anthocyanin content showed a difference between cultivars and extraction systems. VIO juices had the highest contentes of total anthocyanins, while the CON, IP, C30 and ISA cultivars had the lowest values, these results were repeated in both extraction systems in 2018 and 2019. Similar results were found by Lima et al. (2014) who evaluated juices of the VIO and IP cultivars in the São Francisco Valley and found higher contentes of anthocyanins in VIO juices (464.00 $\mathrm{mg} \mathrm{L}^{-1}$ ) and lower values in IP (29.00 $\left.\mathrm{mg} \mathrm{L}^{-1}\right)$. Nassur, Pereira, Alves and Lima (2014) evaluated juices from the COR and IP cultivars on different rootstocks in Petrolina-PE and found values from $22.80 \mathrm{mg} \mathrm{L}^{-1}$ to $168.00 \mathrm{mg} \mathrm{L}^{-1}$ for COR and $35.12 \mathrm{mg} \mathrm{L}^{-1}$ at $43.53 \mathrm{mg} \mathrm{L}^{-1}$ for $\mathrm{PI}$.

The evaluated juices had a higher content of total anthocyanins when prepared by S2. The results show that in 2018 the content of anthocyanins practically doubled in S2 compared to S1 and in 2019 the difference was repeated, however, with values lower than those of the previous year. In S1, the grapes are placed intact in the extraction container, and the steam generated by the extractor pans increases the surface tension of the skin structures and heats the grape, promoting the disruption of the skins and depectinization of the must, facilitating the dragging of compounds present in the skins (Venturin, 2004), however, once the berry is broken, the must/juice flows into the collection container and remains in contact with the solid part for less time. In S2 on the other hand, the grape is previously broken and added with pectinases that are associated with the degradation of soluble pectin, which facilitates the extraction of the compounds from the skins (Lima et al., 2015) and the must/juice is kept in contact with the berries until the moment of pressing which allows a greater liquid/solid contact resulting in a greater anthocyanins supply in the final product.

Another aspect that must be considered to justify the distinction in the results is the process temperature. Malacrida and Mota (2005) explain that the anthocyanins are quickly destroyed, at a logarithmic rate, by the linear temperature increase during the juice processing. Steam extraction subjects the juice to temperatures above $80^{\circ} \mathrm{C}$, causing anthocyanins to degrade, while in the enzymatic extraction method, temperatures above 60 ${ }^{\circ} \mathrm{C}$ are not used (Lima et al., 2014; Roldan, 2016). Roldan (2016) found lower values of anthocyanins in the juices extracted by steam compared to those extracted by the enzymatic system, justifying the difference due to the probable degradation of these compounds by the high temperatures in the extraction.

The content of total phenolic compounds showed a statistical difference between the extraction systems, except for IP juices in 2018 (Table 3). The cultivars VIO, MAG and RUB and CON, ISA and CAR showed a higher contente of polyphenols in the juices prepared 
by S1 in 2018 and 2019, respectively. Most juices had a higher content of total phenolic compounds in S2 compared to S1, except for the aforementioned cultivars. These results are compared with those obtained by Marcon et al. (2013), who found that the juices elaborated by steam distillation had higher contentes of total phenolic compounds in relation to the heat exchanger system. The results of Raldon (2016) corroborate with Marcon et al. (2013) as they demonstrate that the similar amounts of phenolic compounds comparing juices obtained by steam extraction with those by enzymatic method, as these compounds are less thermolabile than anthocyanins and do not reduces with the use of the steam system. Lima et al. (2014) explain that the differences in the phenolic composition may be due to the different technical preparations, processing conditions, cultural practices and grape varieties used in the production of juices.

Among cultivars, the highest contentes of phenolic compounds were found for MAG in S1 and VIO in S2 in 2018 and VIO in 2019 for S1 and S2. C30 showed lower results in both extraction systems in the two crops studied. Burin etal. (2010) and Lima et al. (2014) describe that the contente of phenolic compounds in commercial grape juices in Brazil vary from $270 \mathrm{mg} \mathrm{L}^{-1}$ to $3,433.00 \mathrm{mg} \mathrm{L}^{-1}$. All the evaluated juices, regardless of the extraction system, remained within the average range described by the authors. Values ranged from $1,055.93$ $\mathrm{mg} \mathrm{L}^{-1}$ for $\mathrm{C} 30$ in S1 in 2018 to $3,802.47 \mathrm{mg}$ $\mathrm{L}^{-1}$ for $\mathrm{VIO}$ in $\mathrm{S} 1$ in 2019. Lima et al. (2015) evaluated juices produced in the São Francisco Valley, and found that the highest contentes of phenolic compounds were from $\mathrm{VIO}$ and MAG juices and the lowest values in $\mathrm{PI}$ juices. Toaldo et al. (2015) evaluated organic BOR and conventional BOR/ISA juices produced in São Marcos-RS in an industrial heat exchanger system and found values of $3,378.33 \mathrm{mg} \mathrm{L}^{-1}$ for organic juice and $2,015.00 \mathrm{mg} \mathrm{L}^{-1}$ for the conventional system.

For sensory aspects, the color intensity showed a correlation with the treatment factors (varieties $x$ extraction systems) (Table 4). The juices of the cultivars VIO, IP, MAG, BOR, SCSP and COR did not differ between the extraction systems. The juices of the other cultivars showed greater color intensity when extracted by S2 in the 2018 harvest. In 2019, only cultivars C30, IP, CON, ISA and CAR had greater color intensity for the juices in S2. 
Table 4

Average values of sensory analysis for color intensity in juices elaborated with different grape cultivars in the steam and enzymatic extraction systems in the 2018 and 2019 seasons

\begin{tabular}{ccccc} 
& \multicolumn{4}{c}{ Color Intensity } \\
\cline { 2 - 5 } Cultivars & \multicolumn{3}{c}{2018} & \multicolumn{2}{c}{2019} \\
\cline { 2 - 5 } C30 & S1 & S2 & S1 & S2 \\
VIO & $4.36 \mathrm{Db}$ & $6.68 \mathrm{Da}$ & $4.10 \mathrm{Cb}$ & $6.50 \mathrm{Ba}$ \\
IP & $8.10 \mathrm{Aa}$ & $8.45 \mathrm{Aa}$ & $7.97 \mathrm{Aa}$ & $8.08 \mathrm{Aa}$ \\
MAG & $6.67 \mathrm{Ba}$ & $7.04 \mathrm{Ba}$ & $5.74 \mathrm{Bb}$ & $6.93 \mathrm{Ba}$ \\
BOR & $6.67 \mathrm{Ba}$ & $7.04 \mathrm{Ba}$ & - & - \\
SCSP & $7.90 \mathrm{Aa}$ & $8.25 \mathrm{Aa}$ & $8.00 \mathrm{Aa}$ & $8.07 \mathrm{Aa}$ \\
CON & $7.27 \mathrm{Ba}$ & $7.93 \mathrm{Aa}$ & $7.73 \mathrm{Aa}$ & $8.11 \mathrm{Aa}$ \\
COR & $4.49 \mathrm{Db}$ & $5.47 \mathrm{Da}$ & $4.30 \mathrm{Cb}$ & $5.78 \mathrm{Ba}$ \\
RUB & $6.95 \mathrm{Ba}$ & $7.18 \mathrm{Ba}$ & $7.16 \mathrm{Aa}$ & $6.64 \mathrm{Ba}$ \\
ISA & $6.48 \mathrm{Bb}$ & $7.52 \mathrm{Ba}$ & $7.80 \mathrm{Aa}$ & $8.04 \mathrm{Aa}$ \\
CAR & $5.80 \mathrm{Cb}$ & $7.22 \mathrm{Ba}$ & $5.65 \mathrm{Bb}$ & $7.04 \mathrm{Ba}$ \\
CV(\%) & $6.14 \mathrm{Cb}$ & $7.60 \mathrm{Ba}$ & $4.54 \mathrm{Cb}$ & $6.84 \mathrm{Ba}$ \\
\hline
\end{tabular}

C30-Concord Clone 30; VIO- BRS Violeta; MAG- BRS Magna; BOR- Bordô; IP-Isabel Precoce; CON- Concord; SCSP SCS 421 Paulina; RUB- BRS Rúbea; COR- BRS Cora; ISA- Isabel Precoce; CAR- BRS Carmem. S1- Steam; S2- Enzymatic. * Means followed by the same upper-case letter in the column do not differ by Scott Knott's test at 5\% significance for cultivars within the extraction system. *Means followed by the same lower-case letter in the column do not differ by Scott Knott's test at 5\% significance for extraction system within cultivar.

For the variables acidity, sweetness, sweetness/acidity equilibrium and global impression, there was no interaction between the evaluated factors (varieties $\mathrm{x}$ extraction systems) and these were analyzed separately in the 2018 and 2019 harvests (Table 5). In 2018 , only the sweetness variable showed a difference with the extraction systems, with the greatest sweetness being observed in S2 juices, which corroborates with instrumental analyses, where the juices extracted by $\mathrm{S} 2$ stood out with the higher levels of soluble solids and reducing sugars. In 2019, the juices obtained by S2 showed greater acidity and global impression and less sweetness. The sweetness/acidity equilibrium was not influenced by the extraction method.
Concerning the cultivars, the CON juices differed from the others due to the higher acidity and lower sweetness, sweetness/ acidity equilibrium and global impression in 2018, corroborating again with the results of instrumental acidity analyses. The very high acidity and lower sweetness resulted in the imbalance between sweet and acid, culminating in the lowest global impression. Similar results were found by Bender etal. (2019) in C30 juices, which showed an imbalance due to greater acidity and low sweetness, reflected in the global appreciation, in both extraction systems. Rizzon et al. (2018) explain that a sweetness and acidity equilibrium is fundamental for the juice quality, with the sweet flavor collaborating with the structure, while 
the acidity participates in the freshness and conservation of the product. High acidity and lower global evaluation score for the cultivar CON can be attributed to the lack of adequate ripening, since it occurs in the rainy season and associated with the sensitivity of the berry, it results in an early harvest, that is, before the grapes reach the ideal harvest point.

In 2019, the cultivars VIO, BOR, COR, ISA and CAR were described as presenting the greatest sweetness and C30, IP and COM had the lowest averages for the global impression. Pereira et al. (2008) related the sensory characteristic of the juice to the genetic effect of the cultivar, characteristics of the climate and the soil of the experimental area, grape health, as well as the technology used to extract and obtain the juice.

The principal component analysis, the first two and three dimensions accounted for $76.73 \%$ and $87.55 \%$ of the variance, respectively. There was a positive correlation with PC1 for equilibrium and global impression, and anthocyanins and color intensity, and a negative correlation for luminosity, for PC2, a positive correlation with acidity (sensory and instrumental) was observed (Figures 1a and 1b).

In the score graph (Figure 1c) and the dendrogram (Figure 1d), the most striking aspect was the segregation of the samples according to the method of extraction in CP1. The largest cluster (cluster 2), located on the left in the sample graph, included only juices obtained by steam distillation, characterized by low contentes of soluble solids, color intensity, anthocyanins, lower sweetness, global impression and total acidity, and high lightness (Tables 2,3,4 and 5). The other large cluster (cluster 3), located on the right side of the graph, was formed only by enzymatic extraction samples, which showed high total acidity, soluble solids and anthocyanins content, and high global impression, equilibrium, and low values for luminosity (Tables 2,3 and 5). This behavior highlights that the same grape can generate different juices when subjected to two different extraction systems. It is observed that cultivars with greater color and soluble solids content had less influence from the extraction system.

The exceptions to the formation of only two large clusters - one for each extraction system - were C30_2, CON _2, MAG_1 and VIO_1. Therefore, even when submitted to S2, cultivars CON and C30, give rise to juices (cluster 1, located in the upper left region) with higher sensory acidity and total acidity, and lower values of equilibrium and global impression and more similar to most samples from S1. Regardless of the extraction method, the MAG and VIO cultivars (cluster 4, located in the lower right region) produced similar juices, characterized by high values for anthocyanins, sweetness, color intensity, $\mathrm{pH}$ and soluble solids, and low values for lightness and total acidity, resembling samples from the enzymatic extraction (Figure 1, Tables 2, 3,4 and 5). 


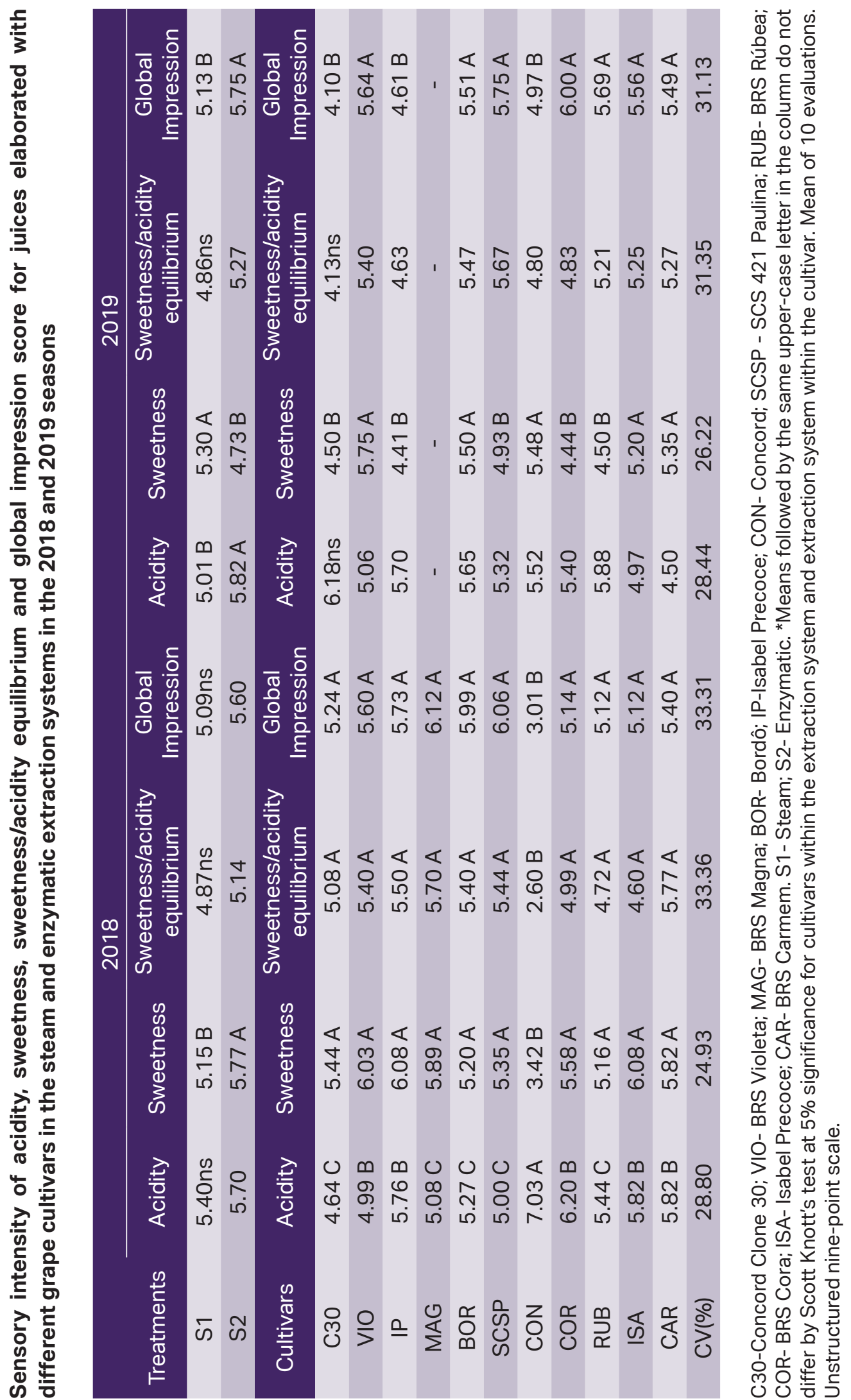




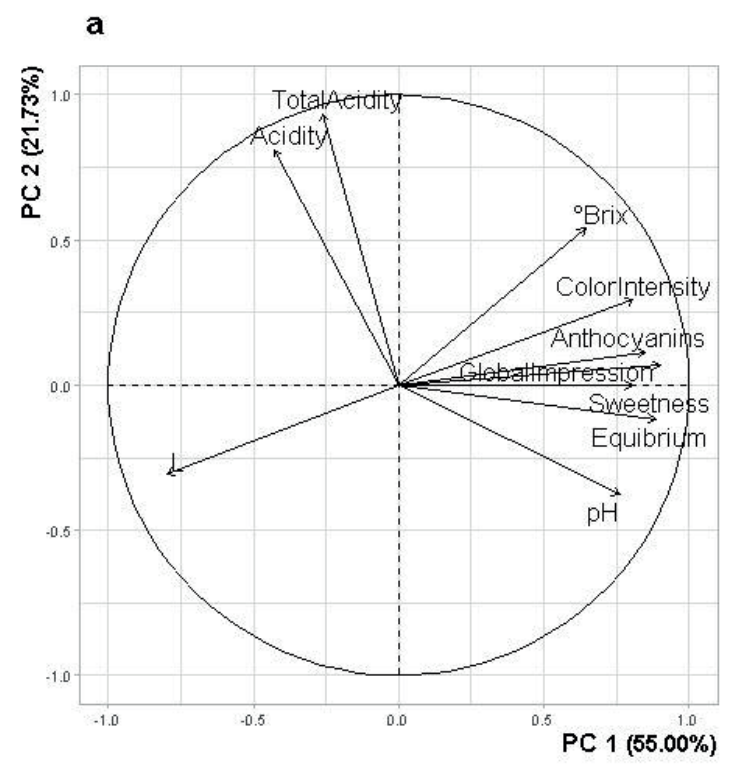

c

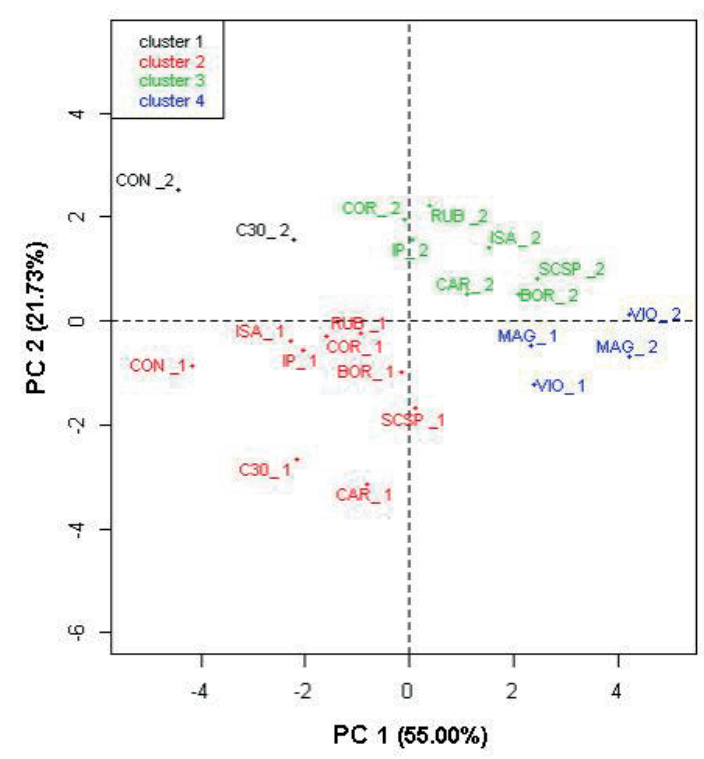

b

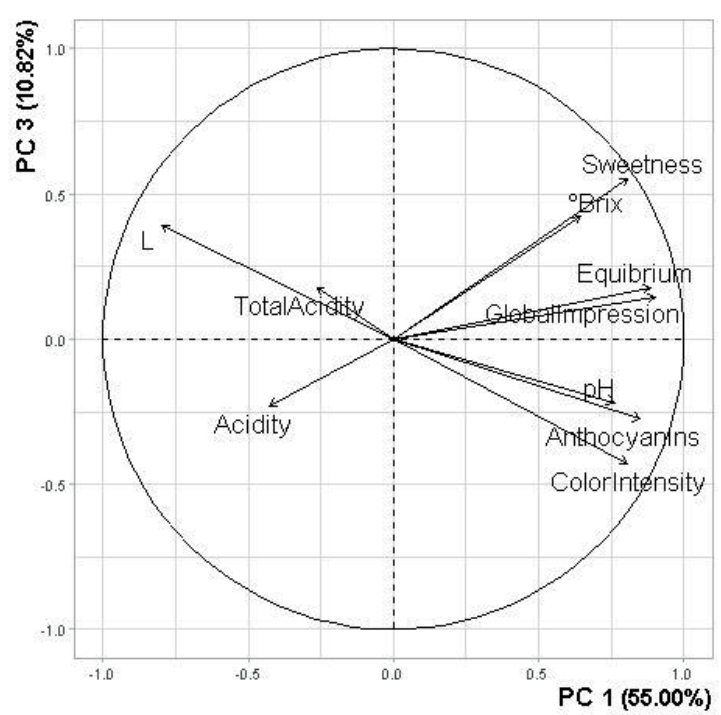

d

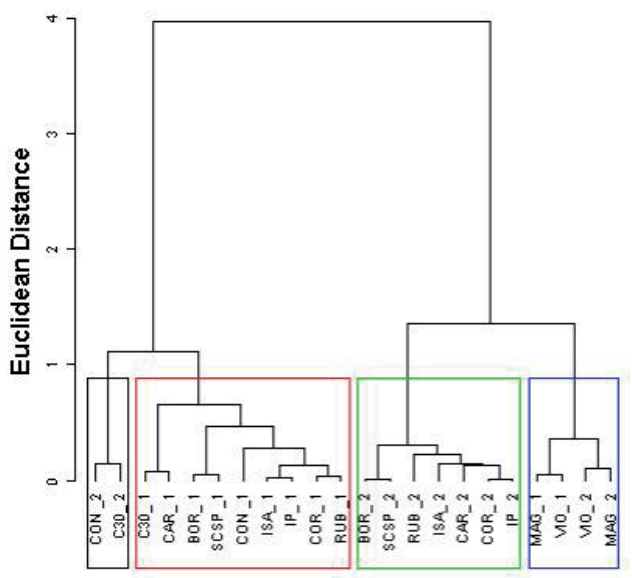

Figure 1. Multivariate analyses a - projection of factor loads (variables) on PC1xPC2 of PCA; $b$ - projection of the factor loadings (variables) on PC1xPC3 of PCA; c - projection of the scores (treatments) on PC1xPC2 of PCA according to the cluster analysis; $d$ - dendogram. Identification of the cultivars BRS Rúbea (RUB), BRS Cora (COR); BRS Violeta (VIO); BRS Carmem (CAR), BRS Magna (MAG), Bordô (BOR), Isabel (ISA), Isabel Precoce (IP), Concord (CON), Concord Clone 30 (C30) and SCS 421 Paulina (SCSP). Identification of extraction systems- S1- Steam; S2- Enzymatic. Instrumental parameters evaluated: Luminosity $\left(\mathrm{L}^{*}\right)$, Soluble Solids ( $\left.{ }^{\circ} \mathrm{Brix}\right), \mathrm{Ph}$, Total Acidity (Total Ac.), Sensory parameters evaluated - Total Anthocyanins, Acidity, Color Intensity, Sweetness, Equilibrium and Global impression. 


\section{Conclusions}

The enzymatic extraction system resulted in juices characterized by a higher content of soluble solids, total acidity, anthocyanins, global impression, equilibrium, and lower luminosity for most varieties.

When the steam extraction system was used, there was a reduction in the soluble solids content in relation to the grape/must.

When extracted by the steam system, the juices do not meet the identity and quality standards for whole grape juice regarding the minimum content of soluble solids, except for the juices of the BRS Violeta and BRS Magna cultivars in 2018 and BRS Violeta and BRS Carmem in 2019.

The juices of the SCS Paulina and Concord cultivars in 2018 and Concord Clone 30, Concord and BRS Rúbea in 2019 were below what is prescribed by law for soluble solids regardless of the extraction system used.

In general, the cultivars gave origin to different juices under different extraction methods, these differences are less expressive in the BRS Violeta and BRS Magna cultivars.

\section{Acknowledgment}

To Fapesc, Finep ans Capes.

\section{References}

Associação Brasileira de Normas Técnicas (2019). NBR ISO 6658:2014: Análise sensorial - metodologia - orientações gerais.
Bender, A., Souza, A. L. K. de, Caliari, V., Malgarim, M. B., \& Camargo, S. S. (2019). Qualidade do suco de uva da variedade Concord Clone 30 elaborado com novo sistema de extração. Revista Brasileira de Tecnologia Agroindustrial, 13(2), 28972913. doi: 10.3895/rbta.v13n2.9532

Bender, A., Souza, A. L. K. de, Caliari, V., Malgarim, M. B., Costa, V. B., \& Goulart, C. (2020). Caracterização físico-química e sensorial de sucos da uva Isabel em cortes com diferentes variedades produzidas na região do Vale do Rio do Peixe-SC. Brazilian Journal of Food Technology, 23(1), 1-11. doi: 10.1590/1981-6723.18719

Borges, R. de S., Roberto, S. R., Yamashita, F., Assis, A. M. de, \& Yamamotoi, L. Y. (2014). Produção e qualidade de frutos de clones de videira 'Concord' sobre diferentes porta-enxertos. Pesquisa Agropecuária Tropical, 44(2), 198-204. doi: 10.1590/ S1983-40632014000200012

Bresolin, B., Gularte, M. A., \& Manfroi, V. (2013). Água exógena em suco de uva obtido pelo método de arraste a vapor. Revista Brasileira de Tecnologia Agroindustrial, 7(1), 922-933. doi: 10.3895/S1981-36 862013000100005

Brighenti, A. F., Allebrandt, R., Munhoz, B., Matos, D. P. de, Regina, M. A., \& Silva, A. L. da. (2018). Qualification of 'Bordô' grape clones in Vale do Rio do Peixe, in the state of Santa Catarina, Brazil. Pesquisa Agropecuária Brasileira, 53(7), 800-808. doi: 10.1590/ s0100-204x2018000700003

Burin, V. M., Falcão, L. D., Gonzaga, L. V., Fett, R., Rosier, J. P., \& Bordignon-Luiz, M. T. (2010). Colour, phenolic content and antioxidant activity of grape juice. Food Science and Technology, 30(4), 1027-1032. doi: 10.1590/S0101-20612010000400030 
Canossa, A. T., Reinehr, J., Bem, B. P. de, Allenbandt, R., Wurz, D. A., \& Kretzchmar, A. A. (2017). Composição química e análise sensorial do suco de uva elaborado com três variedades cultivadas em Lages Santa Catarina. Revista da Jornada de Pós-Graduação e Pesquisa URCAMP, 14(14), 233-245. Retrieved from http:// revista.urcamp.tche.br/index.php/rcjpgp/ article/view/814/510

Chitarra, M. I. F., \& Chitarra, A. B. (2005). Póscolheita de frutos e hortaliças: fisiologia e manuseio (2a ed.). Lavras: Editora UFLA.

Costa, V. B., Andrade, S. B., Lemos, P. L. P. K., Bender, A., Goulart, C., \& Herter, F. G. (2019). Physico-chemical aspects of grape juices produced in the region of Campanha Gaucha, RS, Brazil (Southern Brazil). BIO Web of Conferences, 12(1), 1-4. doi: 10.1051/bioconf/20191201018

Decreto $n^{\circ}$ 8.198, de 20 de fevereiro de 2014 (2014). Ministério da Agricultura, Pecuária e Abastecimento. Regulamenta a Lei $n^{\circ}$ 7.678, de 8 de novembro de 1988, que dispõe sobre a produção, circulação e comercialização do vinho e derivados da uva e do vinho. Diário Oficial [da] República Federativa do Brasil, Brasília, DF, 20 fev. 2014. Seção 1.

Fongaro, C., Cavagnolli, N. I., \& Spada, P. K. W. D. S. (2016). Evaluation of physicochemical parameters of grape juices produced in the Serra Gaúcha. BIO Web of Conferences, 7(1), 1-4. doi: 10.1051/bio conf/20160701008

Frölech, D., Assis, A. M. de, Nadal, M. C., Mello, L. L. de, Oliveira, B. A. dos S., \& Schuch, M. W. (2019). Chemical and sensory analysis of juices and cuts of 'Bordô' and 'Niágara Rosada' grapes. Revista Brasileira de
Fruticultura, 41(2), 1-7. doi: 10.1590/010029452019141

Giusti, M. M., \& Wrolstad, R. E. (2001). Characterization and measurement of anthocyanins by UV-visible spectroscopy. In R. E. Wrolstad (Ed.), Current protocols in food analytical chemistry. New York: John Wiley and Sons Inc.

Guerra, C. C., Bitarelo, H., \& Ben, R. L. (2016). Sistema para elaboração de suco de uva integral em pequenos volumes: suquificador integral. (Documento, 96). Bento Gonçalves: Embrapa Uva e Vinho.

Instrução Normativa $n^{\circ} 24$, de 8 de setembro de 2005 (2005). Ministério da Agricultura, Pecuária e Abastecimento. Aprova o Manual Operacional de Bebidas e Vinagre. Diário Oficial [da] República Federativa do Brasil, Brasília, DF, 20 set.

Instrução Normativa $n^{\circ} 24$, de 30 de agosto de 2012 (2012). Ministério da Agricultura, Pecuária e Abastecimento. Fixar a quantidade mínima de cinquenta por cento de polpa ou suco de uva no Néctar de Uva. Diário Oficial [da] República Federativa do Brasil, Brasília, DF, 31 ago. 2012. Seção 1.

Jolliffe, I. T. (2002). Principal component analysis (2nd ed.). New York: Springer-Verlag.

Lê, S., Josse, J., \& Husson, F. (2008). FactoMineR: An R package for multivariate analysis. Journal of Statistical Software, 25(1), 1-18. doi: 10.18637/jss.v025.i01

Lima, M. dos S., Dutra, M. C. P., Toaldo, I. M., Corrêa, L. C., Pereira, G. E., Oliveira, D., Ninow, J. L. (2015). Phenolic compounds, organic acids and antioxidant activity of grape juices produced in industrial scale by different processes of maceration. Food Chemistry, 188(1), 384-392. doi: 10. 1016/j. foodchem.2015. 04.014 
Lima, M. dos S., Silani, I. de S. V., Toaldo, I. M., Corrêa, L. C., Biasoto, A. C. T., Pereira, G. E., Ninow, J. L. (2014). Phenolic compounds, organic acids and antioxidant activity of grape juices produced from new Brazilian varieties planted in the Northeast Region of Brazil. Food Chemistry, 161(1), 94-103. doi: 10.1016/j.foodchem.2014.03.109

Malacrida, C. R., \& Motta, S. da. (2005). Compostos fenólicos totais e antocianinas em suco de uva. Ciência e Tecnologia de Alimentos, 25(4), 659-664. doi: 10.1590/ S0101-20612005000400006

Maldonade, I. R., Carvalho, P. G. B., \& Ferreira, N. A. (2016). Protocolo para determinação de açúcares totais em hortaliças pelo método DNS. (Comunicado Técnico, 85). Brasília: EMBRAPA.

Mandelli, F. (2002). Relações entre variáveis meteorológicas, fenologia e qualidade da uva na "Serra Gaúcha". Tese de doutorado em Fitotecnia, Faculdade de Agronomia, Universidade Federal do Rio Grande do Sul, Porto Alegre, RS, Brasil.

Marcon, Â. R. (2013). Avaliação da incorporação de água exógena em suco de uva elaborado por diferentes processos. Dissertação de mestrado, Universidade de Caxias do Sul, Caxias do Sul, RS, Brasil.

Marcon, Â. R., Dutra, S. V., Roani, C. A., Spinelli, F. R., Leonardelli, S., Venturin. L., \& Vanderlinde, R. (2016). Avaliação da incorporação de água exógena em sucos de uva elaborados por panela extratora. Revista Brasileira de Viticultura e Enologia, 8(8), 52-57. Retrieved from https:// www.enologia.org.br/ default/uploads/ revista/revista-28.pdf?1900f22d9e3c58 fe81c55334d41b9243
Marcon, Â. R., Dutra, S. V., Spinelli, F. R., Roani, C. A., Venturin, L., \& Vanderlinde, R. (2013). Teores de resveratrol e compostos fenólicos totais em sucos de uva elaborados por diferentes processos. Revista Brasileira de Viticultura e Enologia, 5(5), 66-70. Retrieved from https://www. enologia.org.br/default/uploads/revista/ revista-31.pdf?b1023f31f8c973926ca3e b0a68aaa346

Marzarotto, V. (2005). Suco de uva. In V. G. Fo, Venturini (Ed.), Tecnologia de bebidas. Matéria-prima, processamento, BPF/ APPCC, legislação, mercado. São Paulo: Edgard Blücher.

Mota, R. V. da, Glória, M. B. A., Souza, B. S. de, Peregrino, I., Pimentel, R. M. de A., Dias, F. A. N.,... Regina, M. de A. (2018). Bioactive compounds and juice quality from selected grape cultivars. Bragantia, 77(1), 62-73. doi: 10.1590/1678-4499.2016369

Nassur, R. de C. M. R., Pereira, G. L., Alves, J. Á., \& Lima, L. C. de O. (2014). Chemical characteristics of grape juices from different cultivar and rootstock combinations. Pesquisa Agropecuária Brasileira, 49(7), 540-545. doi: 10.1590/ S0100-204X2014000700006

Pereira, G. E., Lima, L.C. de O., Regina, M. de A., Rosier, J., Ferraz, V., Mourão, M. Jr. (2008). Avaliação do potencial de cinco cultivares de videiras americanas para sucos de uva no sul de Minas Gerais. Ciência e Agrotecnologia, 32(5), 1531-1537. doi: 10.1590/S1413-70542008000500026

$\mathrm{R}$ Core Team (2020). R: A language and environment for statistical computing. New Haven: R Foundation for Statistical Computing. Retrieved from http://www.Rproject.org 
Ribéreau-Gayon, P., Dubourdieu, D., Donèche, B., \& Lonvaud, A. (2006). The grape and its maturation. In P. Ribereau-Gayon, D. Dubourdieu, B. Donèche, \& A. Lonvaud (Eds.), Handbook of enology: the microbiology of wine and vinifcations (pp. 241-297). New York: John Wiley and Sons.

Rizzon, L. A., \& Link, M. (2006). Composição do suco de uva caseiro de diferentes variedades. Ciência Rural, 36(2), 689692. doi: 10.1590/S0103-847820060002 00055

Rizzon, L. A., \& Miele, A. (2012). Analytical characteristics and discrimination of Brazilian commercial grape juice, nectar, and beverage. Ciência e Tecnologia de Alimentos, 1(32), 93-97. doi: 10.1590/ S0101-20612012005000015

Rizzon, L. A., Meneguzzo, J., \& Manfroi, V. (1998). Elaboração de suco de uva na propriedade vitícola. (Documentos, 21). Bento Gonçalves: EMBRAPA Uva e Vinho.

Roldan, B. B. (2016). Influência do método de extração sobre a composição química de suco de uva Bordô (Vitis labrusca). Dissertação de mestrado, Universidade Federal do Rio Grande do Sul, Porto Alegre, RS, Brasil.
RStudio Team (2020). RStudio: integrated development for $R$. Retrieved from http:// www.rstudio.com/

Singleton, V., \& Rossi, J. (1965). Colorimetry of total phenolics with phosphomolybdic phosphotungstic acid reagents. American Journal of Enology and Viticulture, 16(1), 144-158. Retrieved from https://www. ajevonline.org/content/16/3/144

Toaldo, I. M., Cruz, F. A., Alves, T. L., Gois, J. S., Borges, D. L. G., Cunha, H. P., BordignonLuiz, M. T. (2015). Bioactive potential of Vitis labrusca L. grape juices from the Southern Region of Brazil: phenolic and elemental composition and effect on lipid peroxidation in healthy subjects. Food Chemistry, 173(1), 527-535. doi: 10.1016/ j.foodchem.2014.09.171

Vaissie, P., Monge, A, \& Husson, F. (2020). Factoshiny package for $R$.

Venturin, L. (2004.) Influência da temperatura de extração na elaboração de suco de uva Isabel (vitis labrusca) pelo método de arraste a vapor. Bento Gonçalves. Trabalho de conclusão de curso de graduação, Tecnologia em Viticultura e Enologia, Centro Federal de Educação Tecnológica de Bento Gonçalves, Bento Gonçalves, RS, Brasil. 